\title{
Use of chondroitin sulphate and glucosamine sulphate in degenerative changes in TMJ: A systematic review
}

\author{
Eduardo Machado', Patricia Machado², Paulo Afonso Cunali ${ }^{3}$
}

\begin{abstract}
Introduction: Degenerative changes in Temporomandibular Joint (TMJ) have increased in prevalence and severity over the years. Within this context, it's necessary to obtain safe and effective therapies for control and management of the patient in cases of osteoarthritis and osteoarthrosis of the TMJ. Therapeutic options range from intra-articular infiltration protocols, occlusal splints, pharmacological therapies and physiotherapy and educational measures. The alternative treatment with structure-modifying agents, like as chondroitin and glucosamine sulphates, showed promising results, and especially safety. Thus, through a systematic literature review, this study aimed to analyze and discuss effectiveness and safety of chondroitin and glucosamine in degenerative changes of the TMJ.
\end{abstract}

Methods: Survey in research bases MEDLINE, Cochrane, EMBASE, Pubmed, Lilacs and BBO, between the years of 1966 and January 2009, with focus in randomized clinical trial (RCTs) and quasi-randomized clinical trials, systematic reviews and meta-analysis.

Results: After application of the inclusion criteria 2 articles were selected, both randomized controlled double-blind clinical trials, which evaluated the effectiveness of chondroitin and glucosamine in degenerative changes of the TMJ.

Conclusions: There is the necessity of further RCT, with representative samples and long follow-up time, to obtainment more precise cause-effect relationships and to achieve an effective and objective protocol involving chondroitin and glucosamine in cases of degenerative changes of the TMJ.

Keywords: Chondroitin. Glucosamine. Temporomandibular joint. Temporomandibular disorder. Osteoarthrosis. Osteoarthritis.

${ }^{1}$ Specialist in Temporomandibular Disorders and Orofacial Pain, Federal University of Paraná. PhD in Dental Surgery, Federal University of Santa Maria.

${ }^{2}$ Specialist in Prosthodontics, Pontifical Catholic University of Rio Grande do Sul. $\mathrm{PhD}$ in Dental Surgery, Federal University of Santa Maria.

${ }^{3} \mathrm{PhD}$ in Dentistry, Federal University of São Paulo. Professor of Undergraduate and Graduate Programs of Dentistry, Federal University of Paraná. Chairman of Temporomandibular Disorders and Orofacial Pain Residency Program, Federal University of Paraná.

\author{
How to cite this article: Machado E, Machado P, Cunali PA. Use of chondroitin sul- \\ phate and glucosamine sulphate in degenerative changes in TMJ: A systematic re- \\ view. Dental Press J Orthod. 2012 July-Aug;17(4):19.el-5. \\ Submitted: January 19, 2009 - Revised and accepted: August 16, 2009 \\ " The authors report no commercial, proprietary or financial interest in the products \\ or companies described in this article. \\ Contact address: Eduardo Machado \\ Rua Francisco Trevisan, 20 - Santa Maria/RS, Brazil \\ Zip code: 97.050-230 - E-mail: machado.rs@bol.com.br
}




\title{
Utilização de sulfato de condroitina e sulfato de glicosamina nas alterações degenerativas da ATM: uma revisão sistemática
}

\author{
Eduardo Machado', Patricia Machado², Paulo Afonso Cunali ${ }^{3}$
}

\begin{abstract}
Introdução: as alterações degenerativas da Articulação Temporomandibular (ATM) têm aumentado em prevalência e em severidade ao longo dos anos. Dentro desse contexto, surge a necessidade de se obter terapêuticas efetivas e seguras para o controle e o manejo do paciente em situações de osteoartrite e osteoartrose da ATM. As opções terapêuticas variam desde protocolos de infiltrações articulares, dispositivos interoclusais, terapias farmacológicas e medidas fisioterápicas e educacionais. A alternativa de tratamento com agentes modificadores de estrutura - tais como o sulfato de condroitina e o sulfato de glicosamina - apresenta resultados promissores e, principalmente, seguros.
\end{abstract}

Objetivo: através de uma revisão sistemática da literatura, este trabalho teve como objetivo analisar e discutir a efetividade e a segurança da condroitina e da glicosamina nas alterações degenerativas da ATM.

Métodos: levantamento nas bases de dados MEDLINE, Cochrane, Embase, PubMed, LILACS e BBO, no período compreendido entre 1966 e 2009, com enfoque em estudos clínicos randomizados (RCTs) e quase-randomizados, revisões sistemáticas e meta-análises.

Resultados: após a aplicação dos critérios de inclusão, chegou-se a dois artigos (estudos clínicos randomizados controlados e duplo-cegos), que avaliaram a efetividade da condroitina e da glicosamina nas alterações degenerativas da ATM.

Conclusão: existe a necessidade da realização de novos RCTs - com amostras representativas e tempo de acompanhamento longo - para a obtenção de relações causa-efeito mais precisas e para que se consiga um protocolo objetivo e eficaz, envolvendo a condroitina e a glicosamina, em situações de alterações degenerativas da ATM.

Palavras-chave: Condroitina. Glicosamina. Articulação temporomandibular. Síndrome da disfunção da articulação temporomandibular. Transtornos da articulação temporomandibular. Osteoartrite.

${ }^{1}$ Especialista em Disfunções Temporomandibulares (DTM) e Dor Orofacial pela UFPR.

${ }^{2}$ Especialista em Prótese Dentária pela PUCRS.

${ }^{3}$ Doutor em Ciências pela UNIFESP. Professor dos Cursos de Graduação e Pósgraduação em Odontologia da UFPR. Coordenador do Curso de Especialização em DTM e Dor Orofacial da UFPR.

\footnotetext{
Como citar este artigo: Machado E, Machado P, Cunali PA. Use of chondroitin sulphate and glucosamine sulphate in degenerative changes in TMJ: A systematic review. Dental Press J Orthod. 2012 July-Aug;17(4):19.el-5.

Enviado em: 19 de janeiro de 2009 - Revisado e aceito: 16 de agosto de 2009

» Os autores declaram não ter interesses associativos, comerciais, de propriedade ou financeiros que representem conflito de interesse nos produtos e companhias descritos nesse artigo.

Endereço para correspondência: Eduardo Machado Rua Francisco Trevisan, 20 - Santa Maria/RS CEP: 97.050-230 - E-mail: machado.rs@bol.com.br
} 


\section{INTRODUCTION}

Currently, musculoskeletal diseases present as a great public health problem due to the longevity observed in the world population., ${ }^{2,8,9}$ Within this context, osteoarthrosis is a frequent and important situation of morbidity and disability, especially in the second half of life, ${ }^{2}$ increasingly affecting younger patients. Osteoarthrosis or osteoarthritis is a degenerative disease that affects joint tissues, causing damage to the articular cartilage, generating painful symptoms and functional limitations. Regarding this condition, there are few therapies with effective results. ${ }^{10}$

Therapeutic modalities for the control and management of osteoarthrosis are diverse and are related to disease stage, involving patient education, exercise and medication (analgesics and non-steroidal anti-inflammatory drugs - NSAIDs). Eventually, also the orthopedic surgeries are indicated. ${ }^{8}$ In relation to drug therapies, specifically, the treatment is divided into symptoms modifying drugs and structure modifying substances. ${ }^{1,23}$ Symptoms modifier drugs have its performance related to reduction of pain and improvement of function, while the structure modifying substances have its indication associated with structural changes in the joint spaces. ${ }^{7,11}$

The use of NSAIDs has a palliative effect and can cause adverse effects in the long-term. Therefore, effective and safe treatments for the control and management of osteoarthrosis of the Temporomandibular Joint (TMJ) become necessary. Studies focused on this problem showed that the structure-modifying agents, such as chondroitin and glucosamine sulphates, showed positive results, and few or no adverse effects in the treatment of osteoarthrosis of the TMJ, which is attracting increased interest.

Thus, the aim of this systematic literature review is the discussion based on scientific evidences regarding the effectiveness of nutraceuticals, such as glucosamine and chondroitin sulphates, in the treatment of degenerative changes of the TMJ.

\section{MATERIAL AND METHODS}

A search in MEDLINE, Cochrane, EMBASE, PubMed, Lilacs and BBO was made in the period from 1966 to January 2009. The search descriptors used were "chondroitin", "glucosamine", "temporomandibular disorder", "craniomandibular disorder", "temporomandibular joint", "tmd", "tmj” and "osteoarthritis", which were crossed in search engines. The initial list of studies was subjected to review by two reviewers who applied inclusion criteria to determine the final sample of articles, which were evaluated by their title and abstract. If there was any disagreement between reviewers, a third opinion would be consulted after reading the full version of the article.

Inclusion criteria for selecting articles were:

» Studies that have included the effects of structure-modifying agents-chondroitin sulphate and glucosamine sulphate-in situations of degenerative changes of the TMJ.

»Within the context of an Evidence-Based Dentistry, were included only controlled randomized clinical trials (RCTs) and quasi-randomized double-blind, systematic reviews and meta-analysis.

» Articles published from January 1966 until January 2009.

» Articles written in English, Spanish and Portuguese.

\section{RESULTS}

After applying the inclusion criteria, two doubleblind randomized clinical trials were obtained that evaluated the effectiveness of chondroitin and glucosamine sulphates in the treatment of degenerative changes of the TMJ, as shown in Table 1. Still, the Kappa agreement index between reviewers was 1.00, with no need to use a third reviewer.

\section{DISCUSSION}

Considerations about the subject should always be done from a critical reading of the methodology used by different authors. The use of the basic principles of research allows researchers to try to control as best as possible the biases of the study, generating a higher degree of evidence. Thus, methodological criteria as sample size calculation, randomization, blinding, control of involved factors and calibration intra- and inter-examiner become important tools to qualify the level of scientific evidence generated. ${ }^{30}$

Within the context of an Evidence-Based Dentistry, it appears that the most common types of studies published in Brazilian journals correspond to studies with low potential for direct clinical application 


\begin{tabular}{|c|c|c|c|c|c|}
\hline Authors & Study design & Evaluated substance & Sample Size (n) & Follow-up time & Results \\
\hline Nguyen et al ${ }^{19}$ & $\begin{array}{c}\text { Double-blind } \\
\text { and controlled } \\
\text { RCT }\end{array}$ & $\begin{array}{c}\text { Chondroitin } \\
\text { (400 mg 3x daily) and } \\
\text { Glucosamine (500 mg } \\
\text { 3x daily) associated }\end{array}$ & $\begin{array}{l}14 \text { active tt } \\
20 \text { control }\end{array}$ & $\begin{array}{l}12 \text { weeks in patients with } \\
\text { internal changes in the TMJ }\end{array}$ & $\begin{array}{l}\text { Improvement in relation to the } \\
\text { pain, tenderness in TMJ and joint } \\
\text { sounds }\end{array}$ \\
\hline Thie et $\mathrm{al}^{31}$ & $\begin{array}{l}\text { Double-blind } \\
\text { and controlled } \\
\text { RCT }\end{array}$ & $\begin{array}{l}\text { Glucosamine } \\
\text { (500 mg 3x daily) } \\
\text { Ibuprofen } \\
\text { (400 mg 3x daily) }\end{array}$ & $\begin{array}{l}21 \text { glucosamine tt } \\
18 \text { lbuprofen tt }\end{array}$ & $\begin{array}{l}90 \text { days in patients with } \\
\text { osteoarthritis in the TMJ }\end{array}$ & $\begin{array}{l}\text { Glucosamine more effective in } \\
\text { decreasing pain than lbuprofen }\end{array}$ \\
\hline
\end{tabular}

Table 1 - Characteristics of included studies.

$\mathrm{RCT}$ : randomized clinical trial; tt: treatment.

and low level of evidence. The low number of studies with greater strength of evidence shows the need to expand the knowledge of evidence-based methods among researchers. ${ }^{21}$ Likewise, it is important to know, both the authors and the readers, the studies that generate the highest levels of scientific evidence, such as meta-analysis, systematic reviews and randomized clinical trials.

Glucosamine is one of the main pillars of the structural matrix of connective tissue of joints, besides to be a substrate for the synthesis of glycosaminoglycans, stimulating synthesis and inhibiting its degradation. It also has a protective effect in the body against oxidative damage. ${ }^{28}$ Otherwise chondroitin is a glycosaminoglycan found in articular cartilage proteoglycans. ${ }^{32}$ Both compounds are synthesized naturally in each joint. ${ }^{29}$

The exact mechanism of action of chondroitin sulphate ${ }^{32}$ and glucosamine sulphate ${ }^{24,32}$, in the treatment of osteoarthritis, has not been fully elucidated. These substances act synergistically to stimulate glycosaminoglycan synthesis in chondrocytes. Also, combined with the antiprotease action of chondroitin sulphate, provides greater efficacy in delaying the degenerative process. On the other hand, glucosamine has little effect on the inhibition of aggrecanase and collagenase, enzymes responsible for cartilage degradation. ${ }^{14}$

One of the criteria for determining a risk factor is the existence of a biological plausibility, in light of current knowledge, that gives meaning to the association studied. The hypotheses that sustain the plausibility should be supported in experimental studies. ${ }^{3}$ In veterinary medicine, the derivatives of chondroitin and glucosamine have been used successfully for several years in order to treat the symptoms of arthritis. ${ }^{28}$
Chondroitin sulphate of low molecular weight and glucosamine hydrochloride were more effective when combined than alone in reducing the progression of articular cartilage lesions in an instability model of osteoarthritis in rabbits. Thus, it is considered that chondroitin and glucosamine sulphates have overlapping functions in the management of articular cartilage damage. ${ }^{14}$ Furthermore, treatment with chondroitin 4-sulphate decreased the severity of arthritis also in rats, showing minimal evidence of inflammation or joint destruction. Still, the administration of glycosaminoglycan also inhibited significantly increase of TNF- $\alpha{ }^{4}$

Through this systematic literature review it can be verified, in the evaluation of dietary supplements such as glucosamine and chondroitin as a treatment of degenerative changes of the TMJ, that there is a very small number of randomized clinical trials regarding this therapeutic possibility, and there are no meta-analysis or systematic reviews that evaluate this question. Thus, with a small number of significant scientific evidences about the effectiveness and safety of proposed therapies, it is difficult to reach definitive conclusions and extrapolate the results to the general population. Moreover, the selected studies had small samples and a relatively short follow-up time, demonstrating the need for a larger longitudinal follow-up to evaluate the real efficacy and safety of proposed treatments.

The randomized clinical trials included in this systematic literature review compared the chondroitin and/or glucosamine to other therapies, such as NSAIDs and placebo, in cases of degenerative changes of TMJ, and found positive results in reducing pain and improving function. ${ }^{19,31}$ However, what is verified is that there 
are few studies evaluating the TMJ in cases of osteoarthrosis and the influence of structure-modifying agents in this situation. Therefore, it is proven the need for studies based on representative samples and with long follow-up time, presenting methodological criteria such as randomization, sample size calculation, blinding, control of factors and calibration.

Regarding other joints, such as knees and hips, there was encouraging results in the use of chondroitin and/or glucosamine. Meta-analysis, ${ }^{16,26}$ systematic reviews ${ }^{33}$ and double-blinded randomized clinical trials $^{6,12,18,20,22,24}$ show positive results in cases of osteoarthrosis of joints, both in improving symptoms and function, when treating with chondroitin and/or glucosamine. However, other RCTs showed that these therapies involving dietary supplements have not obtained significant results or more effective than placebo. ${ }^{5,13,15,27}$ It is important to emphasize that many of these studies had limitations such as small samples, problems in the methods of allocation of the sample and methodological biases, which reduced the level of scientific evidence generated. ${ }^{16,25}$

Chondroitin and glucosamine are dietary supplements sold without prescription and often without regulation and control over the quality of the substances. Thus, its indication should be made consciously and based on scientific evidences. The safety of these substances has been demonstrated in several studies, being inexistent or minimal the adverse effects such as gastrointestinal symptoms ${ }^{12,24,27,31}$ and headaches. ${ }^{13,17,24,27}$ Similar results were also obtained in control groups.

Due to the safety of the structure-modifying agents, its indication can be useful even if the efficiency is low $^{16}$. In treatment protocols for degenerative changes of the TMJ, chondroitin and glucosamine can be a safe alternative treatment, free from adverse effects related to therapy with NSAIDs. ${ }^{31}$ Thus, associated to protocols with intra-articular injections with corticosteroids, viscosupplementation with sodium hyaluronate, occlusal splints, drug therapies, physiotherapy and educational measures, among others, the structure-modifying agents are added, providing an arsenal in the control and management of degenerative changes of TMJ.

Regarding the recommended dose of glucosamine sulphate, various protocols are used. A daily dose of 1,500 mg, ${ }^{19,29}$ divided into three doses (500 $\mathrm{mg}$ each) is the protocol of choice in cases of osteoarthritis/osteoarthrosis. Though the recommended dose for long-term use of chondroitin sulphate is $800^{29}$ to $1,200 \mathrm{mg} / \mathrm{day},{ }^{19}$ also divided into fractional doses, and associations between the two substances are well tolerated by patients. ${ }^{29}$

\section{CONCLUSIONS}

» Regarding the use of chondroitin and glucosamine sulphates in the treatment of degenerative changes of the TMJ due to the small number of RCTs included in this systematic review, it lacks scientific evidences to support its indication as joint treatment protocol for TMJ. However, the included studies demonstrate that chondroitin and glucosamine showed better results than NSAIDs and placebo in the treatment of internal changes of the TMJ.

»In relation to the use of chondroitin and glucosamine in other joints of the human body in cases of osteoarthrosis/osteoarthritis, such as knees and hips, studies with strong levels of evidence, such as meta-analysis, systematic reviews and RCTs demonstrate positive results using structure-modifying agents in reducing pain and improving function, being dietary supplements safe and with little or no adverse effect.

» This systematic literature review showed that it is necessary further randomized clinical trials, based on representative samples and long follow-up time, to assess the effectiveness and safety of proposed treatments for the control and management of degenerative changes of the TMJ. 


\section{REFERENCES}

1. Altman RD, Hochberg M, Moskowitz RW, Schnitzer J. on behalf of the American College of Rheumatology Subcommittee on Osteoarthritis Guidelines. Recommendations for the medical management of osteoarthritis on the hip and the knee. Arthritis Rheum. 2000 Sep;43(9):1905-15.

2. Badia Llach X. Epidemiology and economic consequences of osteoarthritis. In: Reginster JY, Pelletier JP, Martel-Pelletier J, Henrotin Y, Editors. Osteoarthritis: Clinical and Experimental Aspects. New York (NY): Springer; 1999. p. 38-52.

3. Beck JD. Risk Revisited. Community Dent Oral Epidemiol. 1998;26(4): 220-5.

4. Campo GM, Avenoso A, Campo S, Ferlazzo AM, Altavilla D, Calatroni A. Efficacy of treatment with glycosaminoglycans on experimental collagen-induced arthritis in rats. Arthritis Res Ther. 2003;5(3):R122-31.

5. Cibere J, Kopec JA, Thorne A, Singer J, Canvin J, Robinson DB, Pope J, Hong P, Grant E, Esdaile JM. Randomized, double-blind, placebo-controlled glucosamine discontinuation trial in knee osteoarthritis. Arthritis Rheum. 2004 Oct 15;51(5):738-45

6. Clegg DO, Reda DJ, Harris CL, Klein MA, O'Dell JR, Hooper MM, et al. Glucosamine, chondroitin sulfate, and the two in combination for painful knee osteoarthritis. N Engl J Med. 2006 Feb 23;354(8):795-808.

7. Committee for Proprietary Medicinal Products. Points to Consider on Clinical Investigation of Medicinal Products Used in the Treatment of Osteoarthritis. London (UK): European Agency for the Evaluation of Medicinal Products; 1998.

8. Creamer P, Dieppe PA. Novel drug treatment strategies for osteoarthritis. J Rheumatol. 1993 Sep;20(9):1461-4.

9. Creamer P, Hochberg MC. Osteoarthritis. Lancet. 1997 Aug 16;350(9076):503-8

10. Felson DT, Zhang Y. An update on the epidemiology of knee and hip osteoarthritis with a view to prevention. Arthritis Rheum. 1998 Aug;41(8):1343-55.

11. Food and Drug Administration. Guidance for Industry: Clinical Development Programs for Drugs, Devices, and Biological Products Intended for the Treatment of Osteoarthritis. Washington (DC): Food and Drug Administration; 1999

12. Houpt JB, McMillan R, Wein C, Paget-Dellio SD. Effect of glucosamine hydrochloride in the treatment of pain of osteoarthritis of the knee. J Rheumatol. 1999 Nov;26(11):2423-30.

13. Hughes R, Carr A. A randomized, double-blind, placebo-controlled trial of glucosamine sulphate as an analgesic in osteoarthritis of the knee. Rheumatology (Oxford). 2002 Mar;41(3):279-84

14. Lippiello L, Woodward J, Karpman R, Hammad TA. In vivo chondroprotection and metabolic synergy of glucosamine and chondroitin sulfate. Clin Orthop Relat Res. 2000 Dec;(381):229-40.

15. McAlindon T, Formica M, LaValley M, Lehmer M, Kabbara K. Effectiveness of glucosamine for symptoms of knee osteoarthritis: results from an internet-based randomized double-blind controlled trial. Am J Med. 2004 Nov 1;117(9):643-9.

16. McAlindon TE, LaValley MP, Gulin JP, Felson DT. Glucosamine and Chondroitin for Treatment of Osteoarthritis: a systematic quality assessment and meta-analysis. JAMA. 2000 Mar 15;283(11):1469-75. Review.

17. Michel BA, Stucki G, Frey D, De Vathaire F, Vignon E, Bruehlmann P, Uebelhart D. Chondroitins 4 and 6 sulfate in osteoarthritis of the knee: a randomized, controlled trial. Arthritis Rheum. 2005 Mar;52(3):779-86.

18. Müller-Fassbender H, Bach GL, Haase W, Rovati LC, Setnikar I. Glucosamine sulfate compared to ibuprofen in osteoarthritis of the knee. Osteoarthritis Cartilage. 1994 Mar;2(1):61-9.
19. Nguyen P, Mohamed SE, Gardiner D, Salinas T. A randomized double-blind clinical trial of the effect of chondroitin sulfate and glucosamine hydrochloride on temporomandibular joint disorders: a pilot study. Cranio. 2001 Apr;19(2):130-9.

20. Noack W, Fischer M, Förster KK, Rovati LC, Setnikar I. Glucosamine sulfate in osteoarthritis of the knee. Osteoarthritis Cartilage. 1994 Mar;2(1):51-9.

21. Oliveira GJ, Oliveira ES, Leles CR. Tipos de delineamento de pesquisa de estudos publicados em periódicos odontológicos brasileiros. Rev Odonto Ciênc. 2007;22(55):42-7.

22. Pavelká K, Gatterová J, Olejarová M, Machacek S, Giacovelli G, Rovati LC. Glucosamine sulfate use and delay of progression of knee osteoarthritis: a 3-year, randomized, placebo-controlled, double-blind study. Arch Intern Med. 2002 Oct 14;162(18):2113-23.

23. Pendleton A, Arden N, Dougados M, Doherty M, Bannwarth B, Bijlsma JW, et al. EULAR recommendations for the management of osteoarthritis: report of a task force of the Standing Committee for International Clinical Studies Including Therapeutic Trials (ESCISIT). Ann Rheum Dis. 2000 Dec;59(12):936-44.

24. Reginster JY, Deroisy R, Rovati LC, Lee RL, Lejeune E, Bruyere O, et al. Long-term effects of glucosamine sulphate on osteoarthritis progression: a randomized, placebo-controlled clinical trial. Lancet. 2001 Jan 27;357(9252):251-6.

25. Reichenbach S, Sterchi R, Scherer M, Trelle S, Bürgi E, Bürgi U, et al. Meta-analysis: Chondroitin for Osteoarthritis of the Knee or Hip. Ann Intern Med. 2007 Apr 17;146(8):580-90

26. Richy F, Bruyere O, Ethgen O, Cucherat M, Henrotin Y, Reginster JY. Structural and symptomatic efficacy of glucosamine and chondroitin in knee osteoarthritis: a comprehensive meta-analysis. Arch Intern Med. 2003 Jul 14;163(13):1514-22.

27. Rindone JP, Hiller D, Collacott E, Nordhaugen N, Arriola G. Randomized, controlled trial of glucosamine for treating osteoarthritis of the knee. West J Med. 2000 Feb;172(2):91-4.

28. Rubin BR, Talent JM, Kongtawelert P, Pertusi RM, Forman MD, Gracy RW. Oral polymeric $\mathrm{N}$-acetyl-D-glucosamine and osteoarthritis. J Am Osteopath Assoc. 2001 Jun;101(6):339-44

29. Simánek V, Kren V, Ulrichová J, Gallo J. The efficacy of glucosamine and chondroitin sulfate in the treatment of osteoarthritis: are these saccharides drugs or nutraceuticals? Biomed Pap Med Fac Univ Palacky Olomouc Czech Repub. 2005 Jun;149(1):51-6

30. Susin C, Rosing CK. Praticando odontologia baseada em evidências. Canoas (RS): ULBRA; 1999.

31. Thie NM, Prasad NG, Major PW. Evaluation of glucosamine sulfate compared to ibuprofen for the treatment of temporomandibular joint osteoarthritis: a randomized double blind controlled 3 month clinical trial. J Rheumatol. 200 Jun;28(6):1347-55.

32. Towheed TE, Anastassiades TP. Glucosamine and chondroitin for treating symptoms of osteoarthritis: evidence is widely touted but incomplete. JAMA. 2000 Mar 15;283(11):1483-4.

33. Towheed TE, Maxwell L, Anastassiades TP, Shea B, Houpt J, Robinson V, et al. Glucosamine therapy for treating osteoarthritis (Cochrane Review). Cochrane Database Syst Rev. 2005 Apr 18;(2):CD002946. Review. 